\title{
ЗАКОНОМЕРНОСТИ БИОСИНТЕЗА ЛИПОЛИТИЧЕСКИХ ФЕРМЕНТОВ КСИЛОТРОФНЫМ БАЗИДИОМИЦЕТОМ FOMES FOMENTARIUS
}

\author{
Альмяшева Н.Р. ${ }^{1}$, Голышкин А.В. ${ }^{1}$ \\ ${ }^{1}$ ФГБОУ ВО «Российский Государственный университет нефти и газа (НИУ) имени И.М. Губкина», Москва, е- \\ mail: almyashevanelya@mail.ru \\ Ксилотрофный базидиомицет Fomes fomentarius (L.) Fr. известен как продуцент широкого спектра \\ окислительных и гидролитических ферментов, отвечающих за расщепление лигноцеллюлозного \\ комплекса. В результате работы была установлена способность грибов данного вида продуцировать \\ липолитические ферменты, находящие в современной биотехнологии все более широкое применение. Из \\ 6 штаммов, выделенных с различных природных субстратов, был отобран $F$. fomentarius 12.13 как \\ наиболее перспективный продуцент. Исследование липолитической активности поверхностной и \\ погруженной культур базидиомицета показало, что наличие в питательной среде таких субстратов, как \\ сусло, молочная сыворотка и пептон способствует активному биосинтезу липаз. Максимальная \\ активность внеклеточных ферментов была получена через 120 ч погруженного культивирования и \\ составила 107,1 мU/мл культуральной жидкости, внутриклеточных ферментов - 4,9 мU/мг мицелия через \\ 144 ч.
}

Ключевые слова: Fomes fomentarius, липаза, базидиомицеты, погруженное культивирование

\section{BIOSYNTHESYS OF LIPOLYTIC ENZYMES BY XYLOTROPHIC BASIDIOMYCETE FOMES FOMENTARIUS}

\author{
Almyasheva N.R. ${ }^{1}$, Golyshkin A.V. ${ }^{1}$
}

${ }^{1}$ Federal State Budgetary Educational Institution of Higher Education «Gubkin Russian State University of Oil and Gas (National Research University)», Moscow, e-mail: almyashevanelya@mail.ru

Xylotrophic basidiomycete Fomes fomentarius (L.) Fr is known as a producer of a broad spectrum of oxidative and hydrolytic enzymes responsible for the degradation of the lignocellulosic complex. The study found that fungi of this species can produce lipolytic enzymes, which are widely used in biotechnology. Fomes fomentarius 12.13 was selected from 6 strains isolated from different natural substrates as the most promising producer. The study of lipolytic activity in submerged and surface cultures of basidiomycete showed that the presence of malt extract, milk serum and peptone in the medium promotes the lipase biosynthesis. The maximum exocellular enzyme activity was obtained after $120 \mathrm{~h}$ of submerged cultivation and amounted to $107.1 \mathrm{mU} / \mathrm{ml}$, endocellular enzyme activity $-\mathbf{4 . 9} \mathrm{mU} / \mathrm{ml}$ after $144 \mathrm{~h}$.

Keywords: Fomes fomentarius, lipase, basidiomycetes, submerged cultivation

В связи с интенсивным развитием биотехнологии актуальным становится поиск новых эффективных продуцентов липолитических ферментов. Ксилотрофные базидиомицеты обладают развитым ферментативным аппаратом, позволяющим им разлагать различные органические вещества природного происхождения. [19]. Наиболее изучены окислительные ферменты (лакказы, КФ 1.10.3.2; лигнинпероксидазы, КФ 1.11.1.14; марганецпероксидазы, КФ 1.11.1.13), ответственные за расщепление лигнина [9]. Для предобработки растительного сырья с целью получения биоэтанола интересны базидиомицеты Ceriporiopsis subvermispora (Pilát) Gilbn. \& Ryv. и Pycnoporus cinnabarinus (Jacq.) P.Karst., способные удалять лигнин без разрушения целлюлозы $[7,11]$. Лакказы грибов рода Trametes благодаря широкой субстратной специфичности применяются не только для предобработки лигноцеллюлозной биомассы, но и для биоремедиации почв и воды, загрязненных различными ксенобиотиками 
(в том числе полициклическими ароматическими углеводородами и промышленными красителями) $[8,12,21]$.

Помимо оксидаз базидиомицеты также продуцируют большое количество гидролитических ферментов. Высокая активность амилаз (КФ 3.2.1.1) отмечена у грибов Flammulina velutipes (Curtis) Singer, Hericium erinaceus (Bull.) Pers. и Pleurotus ostreatus (Jacq.) P.Kumm., протеаз (КФ 3.4) - у грибов Piptoporus betulinus (Bull.) P.Karst. и Grifola frondosa (Dicks.) Gray [15]. Наличие липаз отмечено как у ксилотрофных базидиомицетов (Pleurotus sapidus Quél., Schizophyllum commune Fr.), так и у почвенных сапрофитов (Agaricus bisporus (J.E. Lange) Imbach), однако их активность и условия продуцирования исследованы недостаточно [10, 20, 22].

Липазы (триацилглицерин гидролазы, К.Ф.3.1.1.3.) представляют собой важную группу биокатализаторов для биотехнологических процессов. Липолитические ферменты способны осуществлять как гидролиз ацилглицеридов до глицерина и свободных жирных кислот, так и синтетические реакции алкоголиза, ацидолиза и этерификации в среде органических растворителей и водно-органических системах $[13,18]$. Благодаря широкой субстратной специфичности липазы находят применение в процессах очистки сточных вод, в фармацевтической, пищевой и косметической промышленностях, а также для синтеза биополимеров и биодизельного топлива $[13,14,16]$.

Цель настоящей работы - проведение скрининга продуцентов липаз среди грибов, относящихся к виду Fomesfomentarius (L.) Fr., а также выявление закономерностей биосинтеза липолитических ферментов наиболее перспективным штаммом при погруженном культивировании.

\section{Методика}

Реактивы

Трибутирин и глицерин были приобретены у «Sigma-Aldrich» (США), фосфорная кислота, гидрофосфат калия, дигидрофосфат калия были приобретены у «CarlRoth» (Германия), гуммиарабик, олеиновая кислота, сульфат аммония и сульфат магния были приобретены у ООО «Русхим» (Россия), агар-агар, глюкоза, ферментативный пептон и дрожжевой экстракт были приобретены у ООО «НТК ДИАЭМ». В работе использовали полуобезжиренную соевую муку, молочную сыворотку, жидкое сусло (4 по Баллингу) и подсолнечное масло пищевого качества.

\section{Штаммы}

Штаммы $F$. fomentarius $12.02, F$. fomentarius $12.03, F$. fomentarius $12.09, F$. fomentarius 12.13, F.fomentarius 12.14 и F. fomentarius 12.23 выделены из плодовых тел, собранных на территории Московской области. Выделение мицелиальных культур проводили по 
общепринятым методикам на плотной среде, содержащей (г/л водопроводной воды): агарагар - 15,0; жидкое сусло - 30,0 и ферментативный пептон - 3,0 [2, 3]. Принадлежность выделенных культур к базидиомицетам подтверждалась методом световой микроскопии по наличию пряжек на мицелии. Для установления таксономической принадлежности плодовых тел использовали определители базидиальных грибов [4, 5]. Рабочие культуры базидиомицетов хранили на скошенном сусловом агаре при $+4{ }^{\circ} \mathrm{C}$.

Скрининг продуцентов липаз

Скрининг проводили диффузионным методом на среде, содержащей (г/л водопроводной воды): агар-агар - 15,0; трибутирин - 10,0; пептон - 5,0 и дрожжевой экстракт - 3,0. Трибутирин предварительно эмульгировали в воде ультразвуком в течение 1 мин (выходная мощность 85 Вт; ультразвуковой излучатель S-450D, «Branson», США). Чашки Петри засевали агаровыми блоками с 10-дневными культурами базидиомицетов (диаметр 1 мм) и инкубировали при $25^{\circ} \mathrm{C}$ в течение 96 ч, после чего проводили измерение диаметров колоний (d) и зон просветления вокруг них (D). Штамм с наибольшей величиной «гало» (D-d) был выбран для дальнейших исследований.

\section{Подбор компонентов питательной средь}

Штамм F. fomentarius 12.13 выращивали в течение 120 ч при $25^{\circ} \mathrm{C}$ на 42 плотных средах, различающихся сочетаниями источников углерода и азота, после чего вырезали агаровые блоки с мицелием (7 мм × 4 мм) и помещали в центр чашек Петри со средой, содержащей (г/л фосфатного буферного раствора, $\mathrm{pH} 6,5$ ): агар-агар - 15,0; трибутирин - 10,0. Чашки Петри инкубировали при $37{ }^{\circ} \mathrm{C}$ в течение 48 ч. Липолитическую активность оценивали по величине зоны просветления по шкале от «-» (нет активности) до «++++» (высокая активность). В качестве источников углерода использовали глюкозу, жидкое сусло, крахмал, этанол, глицерин, подсолнечное масло, олеиновую кислоту в концентрациях, эквивалентных 20 г/л глюкозы, в качестве источников азота - дрожжевой экстракт, пептон, соевую муку, молочную сыворотку, кукурузный экстракт и нитрат аммония в концентрациях, эквивалентных 10 г/л пептона. Для каждой среды отмечали ростовой коэффициент [3].

\section{Условия культивирования}

Погруженное культивирование проводили в колбах Эрленмейера емкостью 750 мл, содержащих 100 мл среды, при 220 об/мин и температуре $28{ }^{\circ} \mathrm{C}$. Объем посевного материала составлял $10 \%$ объема ферментационной среды. В качестве посевного материала использовали 6-суточную культуру базидиомицета, выращенную в описанных выше условиях на среде, содержащей (г/л водопроводной воды): глюкозу - 20,0; соевую муку 10,$0 ;$ дигидрофосфат калия - 2,5 и сульфат магния - 0,25 [1,6]. 
Биомассу отделяли от культуральной жидкости фильтрованием через лавсановую ткань, фильтрат использовали для дальнейших исследований. Биомассу высушивали при $50{ }^{\circ} \mathrm{C}$ в течение суток.

\section{Определение липазной активности}

Липолитическую активность определяли газохроматографическим методом с использованием эмульсии трибутирина в качестве субстрата. Субстрат готовили добавлением трибутирина (10 \% вес.) в водный раствор гуммиарабика (1 \%вес.) и обработкой смеси ультразвуком в течение 2 мин. К 400 мкл раствора субстрата добавляли 400 мкл фильтрата культуральной жидкости или 10 мг высушенного мицелия в 400 мкл фосфатного буфера (рН 6,5) и инкубировали смесь при $37{ }^{\circ} \mathrm{C}$ в течение 24 часов при постоянном перемешивании. Реакцию ферментативного гидролиза прерывали добавлением 30 мкл фосфорной кислоты (85\%). Реакционную смесь центрифугировали в течение 10 мин при 10000 g, концентрацию масляной кислоты в водной фазе определяли на газовом хроматографе Кристалл-5000.2 («Хроматек», Россия). За единицу активности (U) принимали количество масляной кислоты (нмоль), образующееся при каталитическом воздействии липаз, приходящихся на 1 мл фильтрата культуральной жидкости или 1 мг мицелия.

\section{Результаты и их обсуждение}

Из плодовых тел, собранных с различных природных субстратов, выделено 6 штаммов базидиомицета $F$. fomentarius. Методом фазово-контрастной микроскопии на мицелии всех штаммов были выявлены пряжки - структуры, характерные для представителей отдела Basidiomycota (рис. 1, 2).

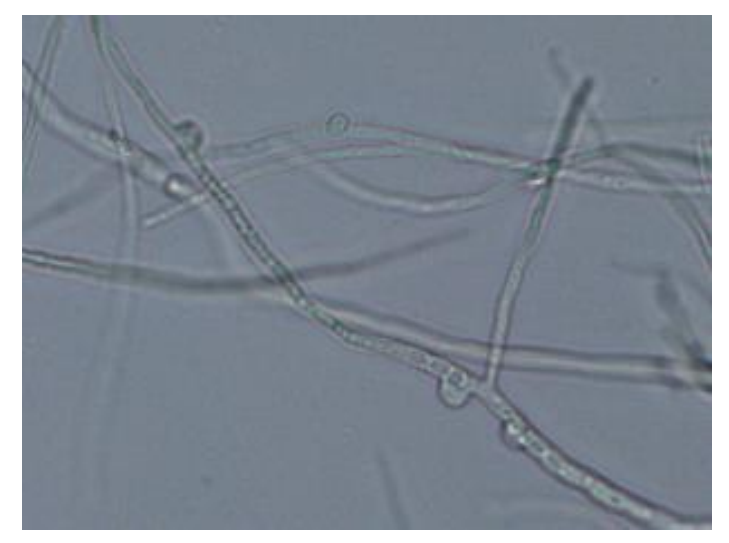

Рис. 1. Микрофотография мицелия F. fomentarius $12.13(\times 400)$

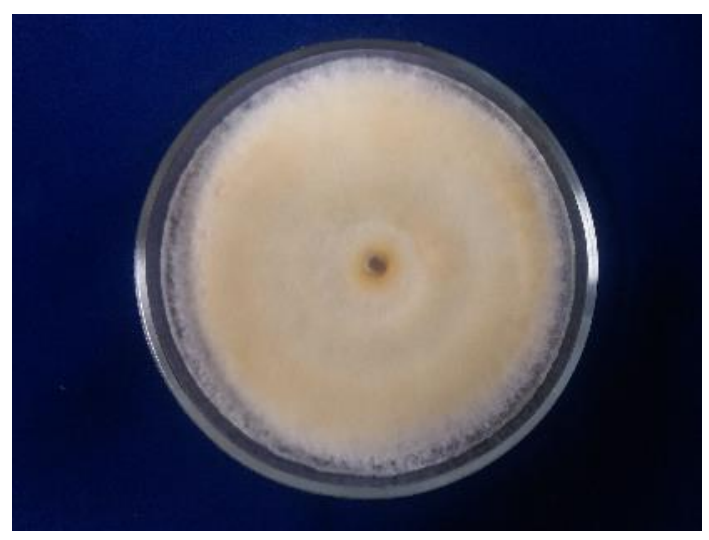

Puc. 2. Культура F. fomentarius 12.13 на сусловом агаре

Скрининг продуцентов липолитических ферментов среди выделенных штаммов проводили диффузионным методом на среде, содержащей трибутирин. В результате ферментативного гидролиза трибутирина вокруг растущих колоний (96 ч культивирования) 
образовывались зоны гидролиза, размер которых варьировал от 7,25 до 14,75 мм (рис. 3). Полученные данные свидетельствовали о способности всех выделенных штаммов продуцировать липазы. Наибольшая зона просветления была отмечена у штамма F. fomentarius 12.13 .

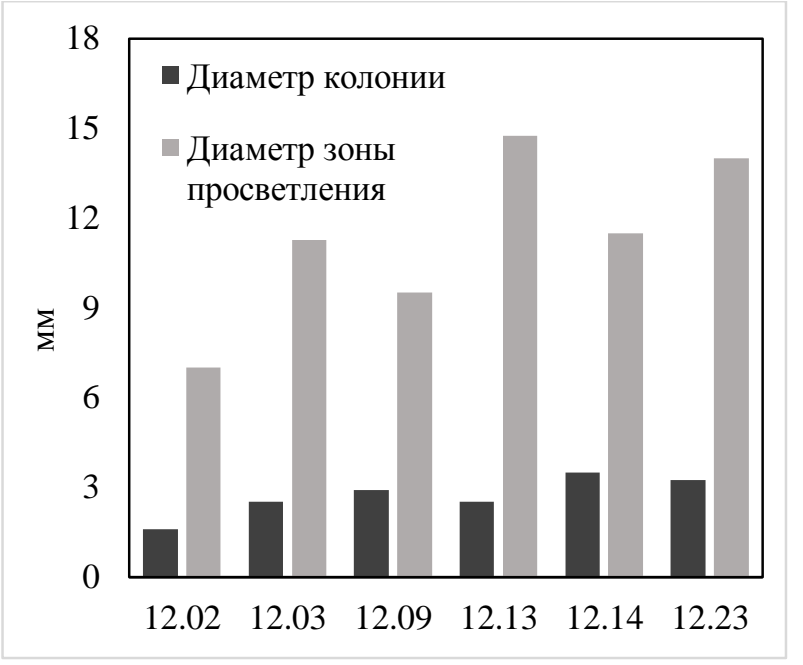

Рис. 3. Скрининг продуцеентов липаз диффузионньмм методом

Исследование роста и липолитической активности $F$.fomentarius 12.13 на 42 питательных средах различного состава показало, что источник углерода не оказывает существенного влияния на продуцирование липаз базидиомицетом (табл. 1).

Таблица 1

Влияние источников углерода и азота в питательной среде на липолитическую активность F. fomentarius 12.13

\begin{tabular}{|l|c|c|c|c|c|c|}
\hline & $\begin{array}{c}\text { Дрожжевой } \\
\text { экстракт }\end{array}$ & Пептон & $\begin{array}{c}\text { Соевая } \\
\text { мука }\end{array}$ & $\begin{array}{c}\text { Молочная } \\
\text { сыворотка }\end{array}$ & $\begin{array}{c}\text { Кукурузный } \\
\text { экстракт }\end{array}$ & $\begin{array}{c}\text { Нитрат } \\
\text { аммония }\end{array}$ \\
\hline Глюкоза & - & +++ & - & +++ & - & - \\
\hline Сусло & - & ++++ & - & +++ & - & - \\
\hline Крахмал & + & +++ & - & +++ & - & - \\
\hline Этанол & - & ++ & - & ++ & - \\
\hline Глицерин & +++ & +++ & - & +++ & + & - \\
\hline $\begin{array}{l}\text { Подсолнечное } \\
\text { масло }\end{array}$ & - & ++ & - & +++ & + & - \\
\hline $\begin{array}{l}\text { Олеиновая } \\
\text { кислота }\end{array}$ & ++ & ++ & - & +++ & - & - \\
\hline
\end{tabular}

Липолитическая активность в баллах: «-» - диаметр зоны просветления 0-11,9 мм; «+» - 12,0-14,9 мм; «++»-15,0-17,9 мм; «+++»-18,0-19,9 мм; «++++»- более 20 мм 
Высокая липолитическая активность была отмечена на средах как с липидными, так и углеводными источниками питания, максимальный ростовой коэффициент был получен на средах, содержащих сусло и крахмал (табл. 2). Среди исследованных источников азота синтезу липаз способствовали пептон и молочная сыворотка, более активному росту базидиомицета - кукурузный экстракт и соевая мука.

Таблица 2

Ростовые коэффициенты базидиомицета $F$. fomentarius 12.13 на плотных средах через 120 ч культивирования

\begin{tabular}{|l|c|c|c|c|c|c|}
\hline & $\begin{array}{c}\text { Дрожжевой } \\
\text { экстракт }\end{array}$ & Пептон & $\begin{array}{c}\text { Соевая } \\
\text { мука }\end{array}$ & $\begin{array}{c}\text { Молочная } \\
\text { сыворотка }\end{array}$ & $\begin{array}{c}\text { Кукурузный } \\
\text { экстракт }\end{array}$ & $\begin{array}{c}\text { Нитрат } \\
\text { аммония }\end{array}$ \\
\hline Глюкоза & 12,45 & 5,55 & 17,10 & 1,15 & 16,50 & 0,50 \\
\hline Сусло & 15,90 & 8,25 & 25,20 & 11,70 & 22,20 & 15,90 \\
\hline Крахмал & 10,65 & 4,05 & 25,65 & 1,33 & 17,11 & 0,50 \\
\hline Этанол & 8,10 & 3,45 & 16,65 & 0,58 & 3,75 & 0,50 \\
\hline Глицерин & 10,65 & 4,05 & 19,65 & 0,83 & 13,30 & 0,50 \\
\hline $\begin{array}{l}\text { Подсолнечное } \\
\text { масло }\end{array}$ & 10,05 & 4,40 & 2,78 & 1,35 & 2,25 & 0,50 \\
\hline $\begin{array}{l}\text { Олеиновая } \\
\text { кислота }\end{array}$ & 10,8 & 0,90 & 2,85 & 1,43 & 2,95 & 0,53 \\
\hline
\end{tabular}

Изучение липолитической активности погруженной культуры базидиомицета проводили, выращивая продуцент на среде с суслом и пептоном в качестве источников углерода и азота, обеспечивших максимальный выход ферментов при культивировании на плотной среде. $\mathrm{B}$ табл.3 представлена динамика накопления внеклеточных и внутриклеточных липаз при погруженном культивировании $F$. fomentarius 12.13 в течение 168 ч. Максимальный выход внеклеточных ферментов был отмечен через 120 ч культивирования (107,1 мU/мл культуральной жидкости), при дальнейшем культивировании базидиомицета содержание липаз в среде резко снижалось. Полученные данные сопоставимы с результатами исследования липолитической активности плесневых грибов. Например, оптимальное время культивирования Penicillium melinii UzLM-4 составило 96 ч [17]. В случае внутриклеточных липаз $F$. fomentarius 12.13 максимальная липолитическая активность была получена через 144 ч культивирования (4,90 мU/мГ мицелия), что соответствовало точке максимума накопления биомассы (0,51 г/100 мл). 
Таблица 3

Динамика накопления биомассы, внутриклеточных и внеклеточных липаз при погруженном культивировании базидиомицета $F$. fomentarius 12.13

\begin{tabular}{|c|c|c|c|}
\hline $\begin{array}{c}\text { Время } \\
\text { культивирования, ч }\end{array}$ & $\begin{array}{c}\text { Содержание } \\
\text { воздушно-сухой } \\
\text { биомассы, г/100 } \\
\text { мл }\end{array}$ & $\begin{array}{c}\text { Активность } \\
\text { внеклеточных липаз, } \\
\text { мU/мл культуральной } \\
\text { жидкости }\end{array}$ & $\begin{array}{c}\text { Активность } \\
\text { внутиклеточных липаз, } \\
\text { мU/мг мицелия }\end{array}$ \\
\hline 24 & $0,13 \pm 0,03$ & $11,55 \pm 1,71$ & $0,35 \pm 0,09$ \\
\hline 48 & $0,21 \pm 0,01$ & $14,87 \pm 4,62$ & $1,12 \pm 0,07$ \\
\hline 72 & $0,29 \pm 0,01$ & $17,57 \pm 0,97$ & $1,92 \pm 0,15$ \\
\hline 96 & $0,46 \pm 0,03$ & $23,01 \pm 3,72$ & $2,44 \pm 0,13$ \\
\hline 120 & $0,48 \pm 0,02$ & $\mathbf{1 0 7 , 0 7} \pm \mathbf{4 , 8 6}$ & $2,99 \pm 0,23$ \\
\hline 144 & $\mathbf{0 , 5 1} \pm \mathbf{0 , 0 3}$ & $56,52 \pm 1,66$ & $\mathbf{4 , 9 0 \pm 0 , 5 5}$ \\
\hline 168 & $0,48 \pm 0,02$ & $36,32 \pm 0,82$ & $4,10 \pm 0,48$ \\
\hline
\end{tabular}

\section{Заключение}

Таким образом, установлена способность ксилотрофных базидиомицетов, относящихся к виду $F$. fomentarius, продуцировать липолитические ферменты. Из 6 штаммов, выделенных из плодовых тел, собранных в природе, был отобран $F$. fomentarius 12.13, характеризующийся высокими показателями скорости роста в погруженной культуре и активности как внутриклеточных, так и внеклеточных липаз. Полученные данные позволяют рассматривать штамм $F$. fomentarius 12.13 как перспективный продуцент ферментов для биотехнологических процессов.

Работа выполнена при финансовой поддержке РФФИ, проект 16-38-00904 мол_а.

\section{Список литературы}

1. Барков А.В., Шуктуева М.И., Тиунов И.А., Винокуров В.А., Краснопольская Л.М. Использование методов оптимизации питательных сред для выявления штаммов базидиомицетов, активно утилизирующих липиды // Башкирский химический журнал. 2013. - T. 20. - №. 4. - c.98-104.

2. Билай В.И., Элланская И.А. Основные микологические методы в фитопатологии. Методы экспериментальной микологии: Справочник. Киев: Наукова думка. - 1982. - 552 с. 
3. Бухало А.С. Высшие съедобные базидиомицеты в чистой культуре. Киев: Наукова думка. - 1988. - 144 с.

4. Гарибова Л.С. Популярный атлас-определитель. Грибы. Москва: Дрофа, 2009. - 352 с.

5. Лессо Т. Грибы: определитель. М.: Астрель, 2007. - 304 с.

6. Соболева П.Ю. Антибиотические свойства штаммов базидиального гриба Lentinus edodes (Berk.) Sing // Антибиотики и химиотерапия. - 2006. - Т. 51. - №. 7. - С. 3-8.

7. Ander P., Eriksson K.E. Selective degradation of wood components by white-rot fungi //Physiologia plantarum. - 1977. - Vol. 41. - №. 4. - P. 239-248.

8. Dodor D.E., Hwang H.M., Ekunwe S.I. Oxidation of anthracene and benzo [a] pyrene by immobilized laccase from Trametes versicolor // Enzyme and Microbial Technology. - 2004. - Vol. 35. - №. 2. - P. 210-217.

9. Fedorova T.V. Comparative analysis of the ligninolytic potential of basidiomycetes belonging to different taxonomic and ecological groups // Applied biochemistry and microbiology. - 2013. - Vol. 49. - №. 6. - P. 570-580.

10. Fermor T.R., Grant W.D. Degradation of fungal and actinomycete mycelia by Agaricus bisporus // Microbiology. - 1985. - Vol. 131. - №. 7. - P. 1729-1734.

11. Ferraz A., Córdova A.M., Machuca A. Wood biodegradation and enzyme production by Ceriporiopsis subvermispora during solid-state fermentation of Eucalyptus grandis // Enzyme and Microbial Technology. - 2003. - Vol. 32. - №. 1. - P. 59-65.

12. Fukuda T. Degradation of bisphenol A by purified laccase from Trametes villosa // Biochemical and biophysical research communications. - 2001. - Vol. 284. - №. 3. - P. 704-706.

13. Gandhi N. N. Applications of lipase // Journal of the American Oil Chemists' Society. 1997. - Vol. 74. - №. 6. - P. 621-634.

14. Gog A. Biodiesel production using enzymatic transesterification - current state and perspectives // Renewable Energy. - 2012. - Vol. 39. - №. 1. - P. 10-16.

15. Krupodorova T., Ivanova T., Barshteyn V. Screening of extracellular enzymatic activity of macrofungi // The Journal of Microbiology, Biotechnology and Food Sciences. - 2014. - Vol. 3. №. 4. - P. 315 .

16. Lanciotti R. Use of Yarrowia lipolytica strains for the treatment of olive mill wastewater // Bioresource Technology. - 2005. - Vol. 96. - №. 3. - P. 317-322.

17. Makhsumkhanov A.A., Yakubov I.T., Davranov K. Conditions for cultivation of the fungus Penicillium melinii UzLM-4 and its biosynthesis of lipases // Applied Biochemistry and Microbiology. - 2003. - Vol. 39. - №. 1. - P. 40-43. 
18. Pencreach G., Baratti J.C. Comparison of hydrolytic activity in water and heptane for thirtytwo commercial lipases preparations // Enzyme and microbial technology. - 2001. - Vol. 28. - №. 4. - P. 473-479.

19. Salvachúa D. Fungal pretreatment: an alternative in second-generation ethanol from wheat straw // Bioresource Technology. - 2011. - Vol. 102. - №. 16. - P. 7500-7506.

20. Singh M. K. Novel lipase from basidiomycetes Schizophyllum commune ISTL04, produced by solid state fermentation of Leucaena leucocephala seeds // Journal of Molecular Catalysis B: Enzymatic. - 2014. - Vol. 110. - P. 92-99.

21. Valmaseda M., Martínez M.J., Martinez A.T. Kinetics of wheat straw solid-state fermentation with Trametes versicolor and Pleurotus ostreatus - lignin and polysaccharide alteration and production of related enzymatic activities // Applied microbiology and biotechnology. - 1991. - Vol. 35. - №. 6. - P. 817-823.

22. Zorn H. Enzymatic hydrolysis of carotenoid esters of marigold flowers (Tagetes erecta L.) and red paprika (Capsicum annuum L.) by commercial lipases and Pleurotus sapidus extracellular lipase // Enzyme and microbial technology. - 2003. - Vol. 32. - №. 5. - P. 623-628. 